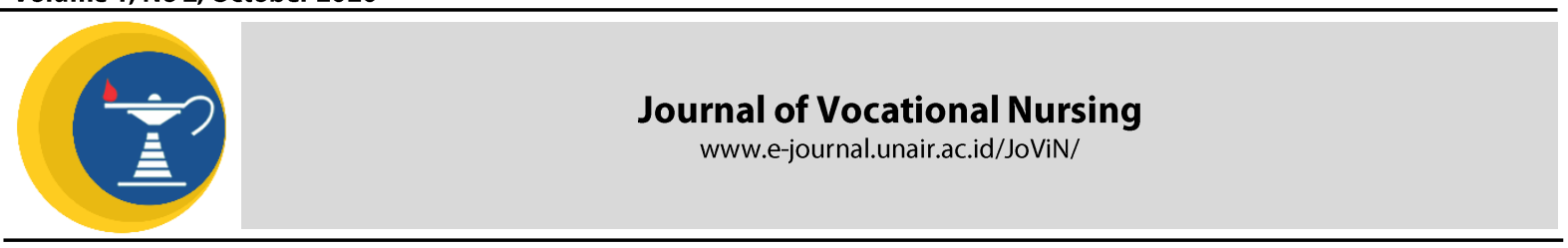

\title{
IDENTIFICATION OF FACTORS RELATED TO MOTIVATION USING VAPORS IN ADOLESCENTS : A LITERATUR REVIEW
}

Septian Galuh Winata ${ }^{1}$ and Voelda Fintriaroqa ${ }^{2}$

Case Study

1,2 Universitas Muhammadiyah Surabaya

\section{ABSTRACT}

Introduction: One of the conventional ways to quit smoking is by using e-cigarettes or vapor. Vapor also has bad effects on health if it is used in long term. However, the fact is that vapor is now being misused, especially among teenagers. It is no longer used as a conventional smoking cessation tool, but as a tool to increase popularity. Methods: A literatur review through journal reviews of factors related to motivation to use vapor in adolescents by searching for articles accessed from the internet database such as Pubmed. There were 10 journals that have been filtered by Tex Availability with the following details: Full Text, Article Type: Journal Articles, Publication Date: last 5 years, type: human, language: English, Journal: MIDLINE and Nursing Journal and discusses the factors that influence using e-cigarettes or vapor. Results: Eight of the ten journals that have been obtained explain that the influence of intrinsic factors, namely expectations and interests. It can affect adolescent motivation to use vapor. In terms of the intrinsic factor such as needs, has been proven to have no significant influence for adolescents using vapor. In addition, seven of the ten journals also explained that extrinsic factors, namely the environment also influenced adolescent motivation to use vapor, but extrinsic factors on family drive and rewards did not explain that they could influence adolescent motivation to use vapor. Conclusion: factors related to using vapor in adolescents are motivated by intrinsic factors which are interests and expectations, and by extrinsic factors, namely environment.

\section{ARTICLE INFO}

Recived 22 October 2020

Accepted 27 October 2020

Online 29 October 2020

*Correspondence:

Septian Galuh Winata

*Email:

septian.ners@fik.um-

surabaya.ac.id

\section{Keywords:}

"factor" OR "cause" AND

"motivation" OR "encouragement" $A N D$ "e-cigarette" $O R$ "vapor" AND

"teenager" $O R$ "adolescence" $O R$

"early teens" OR "mid teens" $O R$ "late teens

\section{INTRODUCTION}

One of the efforts to quit conventional smoking is Nicotine Replacement Therapy (NRT) (WHO, 2010). NRT is a method that uses a medium to provide the nicotine smokers need without burning tobacco. The electric cigarette (vapor) called the WHO Electronic Nicotine Delivery System (ENDS) is one type of NRT. The solution content contained in the vapor is in the form of nicotine, propelin glycol, glycerol, water and various flavorings or flavors (BPOM Rl, 2015). Nicotine has an adverse effect on the human body, resulting in increased adrenaline, increased blood pressure and increased pulse rate(Ministry of Health RI, 2014). Although there are some vapor fluids that do not contain nicotine, the lungs are still exposed to flavor-enhancing chemicals when the liquid is heated and the vapor is inhaled (Ministry of Health, 2018).

Based on the Food and Drug Administration (FDA) research, some products also contain diethylene glycol which is a chemical used for poisoning, so the FDA warns the public about the dangers of toxic substances and carcinogens contained in vapor. Vapor can also lower the immune system, the chemical content in vapor causes popcorn lung, vapor can explode due to overheating, can be addicted, even though the cartridge says nicotin-free, various cases of child poisoning occur in vapor, metal content of vapor vapor is equal even more than conventional cigarette smoke, most of the vapor material contains formaldehyde, the risk of getting lipid pneumonia (Ministry of Health Rl, 2014)

However, the fact is that vapor is currently being misused, especially among young people, vapor is used as a tool to increase popularity or follow trends in the era of globalization, as well as the lifestyle of the millennial generation who are influenced by the glitter of glamorous big cities so that they look up to date and are considered by those around them. In addition, with the 
circulation of various flavoring substances in the liquid which continues to increase significantly, it results in novice smokers (BPOM RI, 2015).

Vapor was first introduced in China in 2004. Since then, awareness and use of vapor has increased exponentially in many countries, especially among teenagers. The highest vapor prevalence in the world in 2013-2015 was in Poland (62.1\%) and the lowest was in Italy (5.9\%). Based on the 2018 Basic Health Research (Riskesdas), data on the proportion of vapor inhaled by the Indonesian population, the most users are the 10-14 year age group at $10.6 \%$, the 15-19 age group $10.5 \%$ and the $20-24$ year age group as much as $7 \%$. Meanwhile, based on urban areas, it was $3.8 \%$ higher than rural areas by $1.6 \%$. The highest number of vapor users was found in the community group who were still in school at $12.1 \%$ and for education levels who had completed D1, D2, D3, S1 were 53.5\%. Based on research (Damayanti, Aspari, 2015) in Surabaya, the majority of the use of vapor is aged 26-35 years $(54.8 \%)$, male $(96.8 \%)$, high school to tertiary education (100\%), working as employees (71\%)

The factors that influence motivation are the electrical and extrinsic factors. Instrumental factors include needs, interests, and expectations. While extrinsic factors include family encouragement, the influence of the surrounding environment and the existence of rewards (Notoatmojo, 2014). (Racmat, Thaha, \& Syafar, 2013) in his research, he explained that there is a relationship between peer group interactions, family interactions, cigarette advertisements, and attitudes with adolescent smoking behavior.

Family environmental factors, namely the lack of supervision from parents and lack of parental knowledge of the whereabouts of adolescents can be a factor in adolescents using vapor, besides that, the influence of parents who smoke and permissive parenting affects the behavior of using vapor. Parents as a model of behavior for children. Teens who live in the same house with smoking parents and often see them smoking will imitate smoking behavior (Racmat, Thaha, \& Syafar, 2013). The second is that the use of vapor lift-style can improve one's social status because of the high price offered and is a trend of style found in cities. Then the highest factor that affects adolescents using vapor is social environmental factors. Teenagers use vapor because they are influenced by invitations from friends, join in with friends, and try it. Besides, they know about vapor from advertisements in online media, shops or stalls that sell vapor. (Ariyanti, Ririanty, \& Iken, 2019).

\section{MATERIALS AND METHODS}

Based on literature search results through NCBI Pubmed publications using keywords "Factor" OR "cause" AND "motivation" OR "encouragement" AND "e-cigarette" OR "vapor" AND "teenager" OR "adolescence" OR "early teens" OR "mid teens" OR "late teens". Researchers found2,118,016 journals that match these keywords. The research journals were then screened, as many as 1,816,091 journals were excluded because publications from 2015 and below, used languages other than English, were not full text, article type: other than journal articles, species: humans and other than Journal: MIDLINE and nursing journal. The feasibility assessment of 301,925 published journals and journals that do not comply with the inclusion criteria will be excluded, so that 10 journals were reviewed. For more details, an overview of the systematic review article selection procedure can be seen in the following picture: 


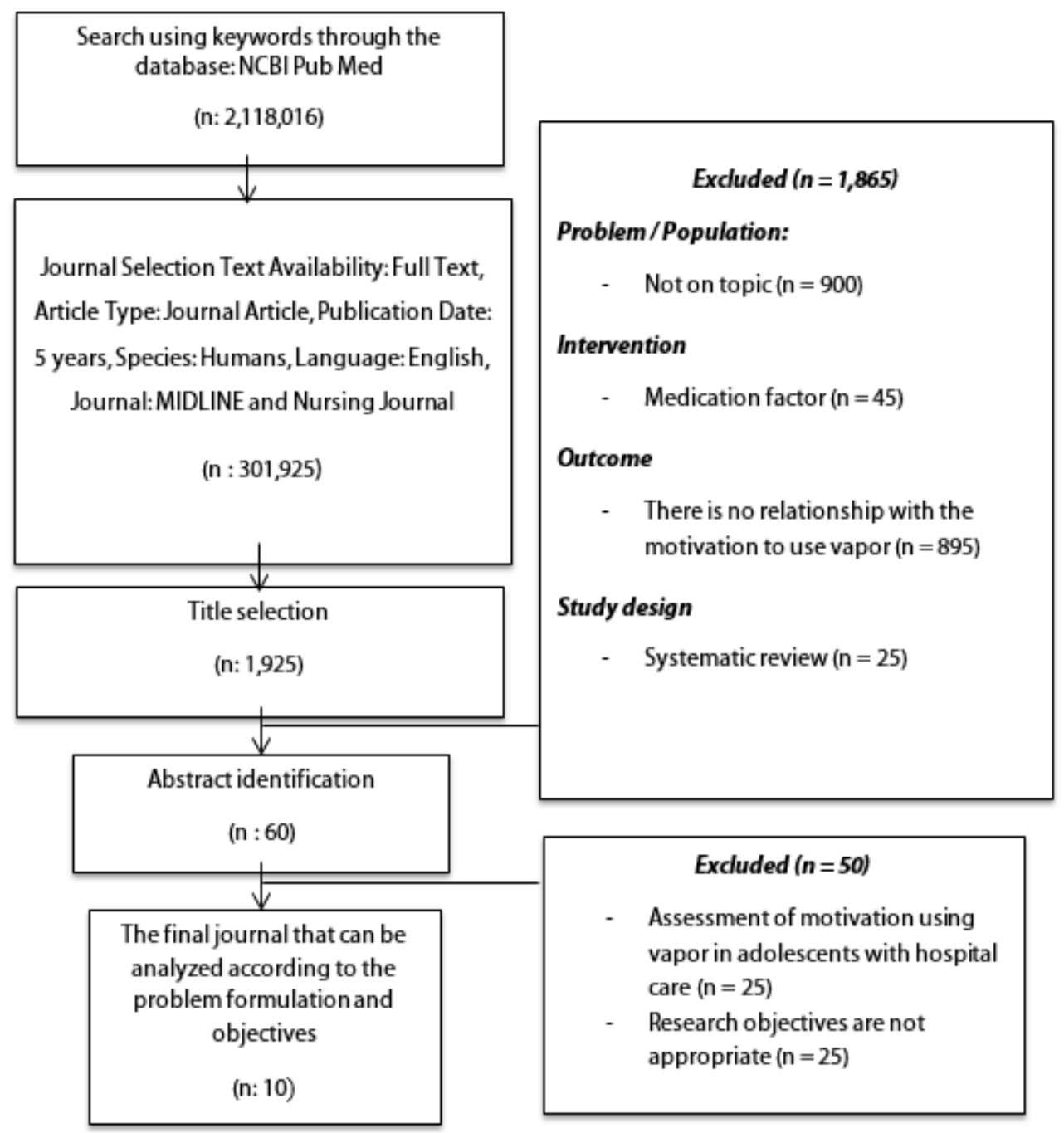

\section{RESULTS}

An article search obtained from the NCBI Pubmed database found 2,118,016 articles that had been adjusted with keywords "Factor" OR "cause" AND "motivation" OR "encouragement" AND "e-cigarette" OR "vapor" AND "teenager" OR "adolescence" OR "early teens" OR "mid teens" OR "late teens", which then after that it is filteredTex Availability: Full Text, Article Type: Journal Article, Publication Date: 5 years, Species: Humans, Language: English, Journal: MIDLINE and Nursing Journal got 301,925articles and then selected the title according to the research topic, namely 1,925 articles, and the Identification of the abstract got 60 articles, then After reading, only 10 articles were taken according to the researchers' objectives that met the inclusion criteria of the researcher. SAfter that the extracted article results can be presented in table form as follows:

\begin{tabular}{|c|c|c|c|c|c|c|}
\hline No. & Title & $\begin{array}{l}\text { Author } \\
\& \text { Year }\end{array}$ & $\begin{array}{l}\text { Research } \\
\text { design, } \\
\text { samples, } \\
\text { variables, } \\
\text { instruments, } \\
\text { analysis } \\
\end{array}$ & Result & Conclusion & Database \\
\hline 1. & $\begin{array}{l}\text { Adolescent } \\
\text { s'interest in } \\
\text { tryingflavo }\end{array}$ & $\begin{array}{l}\text { JK, et } \\
\text { al., } \\
2016\end{array}$ & $\begin{array}{l}\text { Design: } \\
\text { descriptive } \\
\text { correlation. } \\
\text { Sample: } \quad 1125\end{array}$ & $\begin{array}{l}\text { The results of this } \\
\text { study indicate that } \\
\text { adolescents are more } \\
\text { likely to use e-cigarette }\end{array}$ & $\begin{array}{l}\text { It can be } \\
\text { concluded that } \\
\text { the intrinsic } \\
\text { factor, namely }\end{array}$ & Pubmed \\
\hline
\end{tabular}




\begin{tabular}{|c|c|c|c|c|c|c|}
\hline & $\begin{array}{l}\text { ured e- } \\
\text { cigarettes }\end{array}$ & & $\begin{array}{l}\text { adolescents } \\
\text { aged 13-17 } \\
\text { years } \\
\text { Variable: } \\
\text { teenagers' } \\
\text { interest in } \\
\text { trying the taste } \\
\text { of e-cigarettes } \\
\text { Instrument: } \\
\text { questionnaire } \\
\text { Analysis: logistic } \\
\text { regression } \\
\text { analysis }\end{array}$ & $\begin{array}{l}\text { or vapor because of } \\
\text { the interest offered by } \\
\text { a friend because of the } \\
\text { availability of various } \\
\text { flavors such as } \\
\text { menthol or fruit. As } \\
\text { well as teenagers } \\
\text { believe that e- } \\
\text { cigarettes are less } \\
\text { dangerous than } \\
\text { tobaccocigarettes }\end{array}$ & $\begin{array}{l}\text { interest affects } \\
\text { the motivation } \\
\text { of adolescents } \\
\text { to use e- } \\
\text { cigarettes or } \\
\text { vapor }\end{array}$ & \\
\hline 2. & $\begin{array}{l}\text { Factors } \\
\text { associated } \\
\text { with } \\
\text { intentions } \\
\text { to use e- } \\
\text { cigarettes } \\
\text { among } \\
\text { Australian } \\
\text { young } \\
\text { adult non- } \\
\text { smokers }\end{array}$ & $\begin{array}{l}\text { MI } \\
\text { Jongen } \\
\text { eli, et } \\
\text { al., } \\
2019\end{array}$ & $\begin{array}{l}\text { Design: cross- } \\
\text { sectional } \\
\text { Sample: } 429 \\
\text { Australians } \\
\text { aged } 18-25 \\
\text { years } \\
\text { Variables: e- } \\
\text { cigarette use } \\
\text { intention and } \\
\text { perceived } \\
\text { pressure from } \\
\text { others } \\
\text { regarding } \\
\text { cigarette use } \\
\text { Instrument: a } \\
\text { questionnaire } \\
\text { with a web } \\
\text { panel provision } \\
\text { Analysis: } \\
\text { univariate linear } \\
\text { regression } \\
\text { analysis }\end{array}$ & $\begin{array}{l}\text { The results of this } \\
\text { study indicate that } \\
\text { adolescents using e- } \\
\text { cigarettes have greater } \\
\text { user intentions } \\
\text { because of curiosity } \\
\text { about e-cigarette use, } \\
\text { and have friends, } \\
\text { family members who } \\
\text { smoke, and positive } \\
\text { expectations about e- } \\
\text { cigarettes. }\end{array}$ & $\begin{array}{l}\text { It can be } \\
\text { concluded that } \\
\text { the intrinsic } \\
\text { factors, namely } \\
\text { interest due to } \\
\text { curiosity about } \\
\text { e-cigarettes and } \\
\text { extrinsic factors, } \\
\text { namely the } \\
\text { influence of the } \\
\text { surrounding } \\
\text { environment } \\
\text { can affect the } \\
\text { motivation of } \\
\text { adolescents to } \\
\text { use e-cigarettes } \\
\text { or vapor. }\end{array}$ & Pubmed \\
\hline 3. & $\begin{array}{l}\text { Associatio } \\
\mathrm{n} \text { between } \\
\text { Family and } \\
\text { Friend } \\
\text { Smoking } \\
\text { Status and } \\
\text { Adolescent } \\
\text { Smoking } \\
\text { Behavior } \\
\text { and } \mathrm{E}- \\
\text { Cigarette } \\
\text { Use in } \\
\text { Korea }\end{array}$ & $\begin{array}{l}\text { Joung, } \\
\text { et al., } \\
2016\end{array}$ & $\begin{array}{l}\text { Design: } \\
\text { descriptive } \\
\text { correlation } \\
\text { Sample: } 72,060 \\
\text { middle and } \\
\text { high school } \\
\text { students } \\
\text { Variables: } \\
\text { smoking status } \\
\text { of family \& } \\
\text { friends and } \\
\text { current } \\
\text { smoking and } \\
\text { electronic } \\
\text { smoking status } \\
\text { Instrument: The } \\
2014 \quad 15 \\
\text { questionnaire } \\
\text { consisted of } 125 \\
\text { items in } 15 \\
\text { domains of } \\
\text { health behavior. }\end{array}$ & $\begin{array}{l}\text { The results of the study } \\
\text { state that adolescents } \\
\text { using e-cigarettes or } \\
\text { vapor are influenced } \\
\text { by the presence of } \\
\text { family members and } \\
\text { friends who smoke, } \\
\text { and witnessing } \\
\text { smoking in school is } \\
\text { associated with } \\
\text { current smoking and } \\
\text { electronic smoking. }\end{array}$ & $\begin{array}{l}\text { It can be } \\
\text { concluded that } \\
\text { extrinsic factors, } \\
\text { namely the } \\
\text { influence of the } \\
\text { surrounding } \\
\text { environment, } \\
\text { can affect } \\
\text { adolescents } \\
\text { using e- } \\
\text { cigarettes }\end{array}$ & Pubmed \\
\hline
\end{tabular}




\begin{tabular}{|c|c|c|c|c|c|c|}
\hline & & & $\begin{array}{l}\text { Analysis: } \\
\text { descriptive } \\
\text { analysis, chi- } \\
\text { square test and } \\
\text { logistic } \\
\text { regression } \\
\text { analysis }\end{array}$ & & & \\
\hline 4. & $\begin{array}{l}\text { Reasons } \\
\text { for } \\
\text { Electronic } \\
\text { Cigarette } \\
\text { Use } \\
\text { Among } \\
\text { Middle and } \\
\text { High } \\
\text { School } \\
\text { Students - } \\
\text { National } \\
\text { Youth } \\
\text { Tobacco } \\
\text { Survey, } \\
\text { United } \\
\text { States, } \\
\text { 2016 }\end{array}$ & $\begin{array}{l}\text { Tsai, et } \\
\text { al., } \\
2018\end{array}$ & $\begin{array}{l}\text { Design: cross- } \\
\text { sectional } \\
\text { Sample: 20,675 } \\
\text { students in } \\
\text { grades 6-12 } \\
\text { Variable: } \\
\text { reasons for } \\
\text { using e- } \\
\text { cigarettes } \\
\text { among middle } \\
\text { and high school } \\
\text { students } \\
\text { Instrument: } \\
\text { NYTS } \\
\text { questionnaire } \\
\text { Analysis: chi- } \\
\text { square test }\end{array}$ & $\begin{array}{l}\text { The results of the study } \\
\text { stated that among } \\
\text { students who reported } \\
\text { having used e- } \\
\text { cigarettes in } 2016 \text { the } \\
\text { most common reason } \\
\text { for choosing was 1). } \\
\text { Used by friends or } \\
\text { family members, 2). } \\
\text { Availability of flavors } \\
\text { such as mint, perment, } \\
\text { fruit or chocolate, 3). } \\
\text { And it is believed that } \\
\text { e-cigarettes are less } \\
\text { harmful than other } \\
\text { forms of tobacco. }\end{array}$ & $\begin{array}{l}\text { It can be } \\
\text { concluded that } \\
\text { extrinsic factors, } \\
\text { namely the } \\
\text { influence of the } \\
\text { surrounding } \\
\text { environment } \\
\text { and intrinsic } \\
\text { factors, namely } \\
\text { interest, } \\
\text { because the } \\
\text { availability of } \\
\text { taste affects } \\
\text { adolescents } \\
\text { using e- } \\
\text { cigarettes or } \\
\text { vapor. }\end{array}$ & Pubmed \\
\hline 5. & $\begin{array}{l}\text { Reported } \\
\text { electronic } \\
\text { cigarette } \\
\text { use among } \\
\text { adolescent } \\
\mathrm{s} \text { in the } \\
\text { Niagara } \\
\text { region of } \\
\text { Ontario }\end{array}$ & $\begin{array}{l}\text { Khoury } \\
\text {, et al., } \\
2016\end{array}$ & $\begin{array}{l}\text { Design: cross- } \\
\text { sectional } \\
\text { Sample: Grade } 9 \\
\text { students aged } \\
14-15 \text { years as } \\
\text { many as } 3312 \\
\text { respondents } \\
\text { Variables: } \\
\text { motivation to } \\
\text { use e-cigarettes } \\
\text { among } \\
\text { students in } \\
\text { Niagara region, } \\
\text { and } \\
\text { sociodemograp } \\
\text { hic associations } \\
\text { with e-cigarette } \\
\text { use. } \\
\text { Instruments: a } \\
\text { questionnaire } \\
\text { to assess } \\
\text { smoking, e- } \\
\text { cigarettes, and } \\
\text { other tobacco } \\
\text { use, as well as } \\
\text { independently } \\
\text { assessing health } \\
\text { and stress. } \\
\text { Analysis: logistic } \\
\text { regression } \\
\text { analysis }\end{array}$ & $\begin{array}{l}\text { The results of the study } \\
\text { stated that out of } 2321 \\
\text { respondents to } \\
\text { environmental } \\
\text { questions } \\
(51.7 \% \text { ) had family } \\
\text { members who smoked } \\
\text { and } 811 \text { (35.3\%) had } \\
\text { friends who smoked. } \\
\text { Of } 2,278 \text { respondents, } \\
238 \text { (10.4\%) reported } \\
\text { using e-cigarettes. Of } \\
\text { these, 134 (56.3\%) } \\
\text { reported using them } \\
\text { once, while } 79 \text { ( } 33.2 \%) \\
\text { reported using them } \\
\text { "multiple times." The } \\
\text { most common reason } \\
\text { for trying e-cigarettes } \\
\text { is that they are "cool / } \\
\text { fun / something new" } \\
\text { (n = 171, } 71.8 \% \text { ), while } \\
15 \\
\text { respondents use them } \\
\text { to help quit smoking }\end{array}$ & $\begin{array}{l}\text { It can be } \\
\text { concluded that } \\
\text { extrinsic factors, } \\
\text { namely the } \\
\text { influence of the } \\
\text { surrounding } \\
\text { environment } \\
\text { and intrinsic } \\
\text { factors, namely } \\
\text { the hope of } \\
\text { looking cool, } \\
\text { affect } \\
\text { adolescents } \\
\text { using o- } \\
\text { cigarettes or } \\
\text { vapor. }\end{array}$ & Pubmed \\
\hline
\end{tabular}




\begin{tabular}{|c|c|c|c|c|c|c|}
\hline 6. & $\begin{array}{l}\text { A } \\
\text { Randomize } \\
d \text { Trial of } \\
\text { the Effect } \\
\text { of E- } \\
\text { cigarette } \\
\text { TV } \\
\text { Advertise } \\
\text { ments on } \\
\text { Intentions } \\
\text { to Use E- } \\
\text { cigarettes }\end{array}$ & $\begin{array}{l}\text { Farrelly } \\
\text {, et al., } \\
2015\end{array}$ & $\begin{array}{l}\text { Design: } \\
\text { experimental } \\
\text { design } \\
\text { Sample: } 3,655 \\
\text { adolescents } \\
\text { aged 13-17 } \\
\text { years } \\
\text { Variables: effect } \\
\text { of e-cigarette } \\
\text { advertising and } \\
\text { intention to use } \\
\text { e-cigarettes } \\
\text { Instrument: } \\
\text { questionnaire } \\
\text { Analysis: chi- } \\
\text { square test }\end{array}$ & $\begin{array}{l}\text { The results of these } \\
\text { studies suggest that } \\
\text { the effects of e- } \\
\text { cigarette exposure can } \\
\text { persuade teenagers to } \\
\text { try e-cigarette } \\
\text { products. Adolescents } \\
\text { in the treatment group } \\
\text { reported a greater } \\
\text { likelihood of future e- } \\
\text { cigarette use } \\
\text { compared to the } \\
\text { control group, and } \\
\text { adolescents tried using } \\
\text { e-cigarettes if a friend } \\
\text { offered them }\end{array}$ & $\begin{array}{l}\text { It can be } \\
\text { concluded that } \\
\text { extrinsic factors, } \\
\text { namely the } \\
\text { influence of the } \\
\text { surrounding } \\
\text { environment } \\
\text { can affect } \\
\text { adolescents } \\
\text { using o- } \\
\text { cigarettes or } \\
\text { vapor. }\end{array}$ & Pubmed \\
\hline 7. & $\begin{array}{l}\text { Reasons to } \\
\text { use } \\
\text { ecigarettes } \\
\text { and } \\
\text { association } \\
\text { s with } \\
\text { other substances } \\
\text { among } \\
\text { adolescent } \\
\text { s in } \\
\text { Switzerlan } \\
\text { d }\end{array}$ & $\begin{array}{l}\text { JC. } \\
\text { Suris, } \\
\text { et al., } \\
2015\end{array}$ & $\begin{array}{l}\text { Design: cross- } \\
\text { sectional } \\
\text { Sample: sample } \\
621 \text { adolescents } \\
\text { Variables: } \\
\text { reasons for } \\
\text { adolescents } \\
\text { using e- } \\
\text { cigarettes, and } \\
\text { assessing in } \\
\text { differences in } \\
\text { experiments \& } \\
\text { e-cigarette use } \\
\text { based } \\
\text { personal on } \\
\text { characteristics, } \\
\text { and } \\
\text { determine } \\
\text { whether their } \\
\text { use } \\
\text { associated with } \\
\text { other substance } \\
\text { use among } \\
\text { representative } \\
\text { youth } \\
\text { Switzerland. } \\
\text { Instrument: } \\
\text { questionnaire } \\
\text { Analysis: } \\
\text { multinominal } \\
\text { regression and } \\
\text { multivariable } \\
\text { analysis }\end{array}$ & $\begin{array}{l}\text { The results of the study } \\
\text { stated that } 43 \% \text { had } \\
\text { tried e-cigarettes and } \\
\text { the main reason was } \\
\text { curiosity, compared to } \\
\text { not using, } \\
\text { experimental people } \\
\text { were more likely to } \\
\text { leave school and abuse } \\
\text { alcohol, while users } \\
\text { were more likely to be } \\
\text { male, vocational } \\
\text { students or students } \\
\text { not attending school. }\end{array}$ & $\begin{array}{l}\text { It can be } \\
\text { concluded that } \\
\text { the intrinsic } \\
\text { factor, namely } \\
\text { interest due to } \\
\text { curiosity about } \\
\text { e-cigarettes, } \\
\text { can influence } \\
\text { the motivation } \\
\text { of adolescents } \\
\text { to use e- } \\
\text { cigarettes or } \\
\text { vapor. }\end{array}$ & Pubmed \\
\hline 8. & $\begin{array}{l}\text { E-cigarette } \\
\text { openness, } \\
\text { curiosity, } \\
\text { harm } \\
\text { perception } \\
\text { S and } \\
\text { advertising } \\
\text { exposure }\end{array}$ & $\begin{array}{l}\text { Margol } \\
\text { is, et al., } \\
2019\end{array}$ & $\begin{array}{l}\text { Design: cross- } \\
\text { sectional } \\
\text { Sample: } \\
\text { students in } \\
\text { grades } 6-12 \text { as } \\
\text { many as } 17,711 \\
\text { respondents }\end{array}$ & $\begin{array}{l}\text { The results of the study } \\
\text { stated that among the } \\
\text { respondents who had } \\
\text { never used tobacco } \\
\text { products, } 2.3 \% \text { were } \\
\text { open to using e- } \\
\text { cigarettes and } 25.4 \% \\
\text { were interested }\end{array}$ & $\begin{array}{l}\text { It can be } \\
\text { concluded that } \\
\text { the intrinsic } \\
\text { factors, namely } \\
\text { interests and } \\
\text { extrinsic factors, } \\
\text { namely the } \\
\text { influence of the }\end{array}$ & Pubmed \\
\hline
\end{tabular}




\begin{tabular}{|c|c|c|c|c|c|c|}
\hline & $\begin{array}{l}\text { among US } \\
\text { middle and } \\
\text { high } \\
\text { school } \\
\text { students }\end{array}$ & & $\begin{array}{l}\text { Variables: e- } \\
\text { cigarette } \\
\text { openness and } \\
\text { perceived } \\
\text { dangers and e- } \\
\text { cigarette } \\
\text { advertising } \\
\text { Instrument: } \\
\text { NYTS } \\
\text { questionnaire } \\
\text { Analysis: logistic } \\
\text { regression and } \\
\text { multinominal } \\
\text { logistic } \\
\text { regression }\end{array}$ & $\begin{array}{l}\text { because of their } \\
\text { exposure to e- } \\
\text { cigarettes. Only a few } \\
\text { respondents thought } \\
\text { that e-cigarettes were } \\
\text { dangerous. } \\
\text { Respondents exposed } \\
\text { to e-cigarette } \\
\text { advertisements in } \\
\text { stores have a greater } \\
\text { chance of using e- } \\
\text { cigarettes }\end{array}$ & $\begin{array}{l}\text { environment } \\
\text { around the } \\
\text { existence of e- } \\
\text { cigarette } \\
\text { advertisements, } \\
\text { affect } \\
\text { adolescents } \\
\text { using e- } \\
\text { cigarettes or } \\
\text { vapor. }\end{array}$ & \\
\hline 9. & $\begin{array}{l}\text { Offers of } \\
\text { Cigarettes } \\
\text { and E- } \\
\text { Cigarettes } \\
\text { Among } \\
\text { HighSchoo } \\
\text { I Students: } \\
\text { A } \\
\text { Population } \\
\text { Study from } \\
\text { California }\end{array}$ & $\begin{array}{l}\text { AG } \\
\text { Cole, et } \\
\text { al., } \\
2019\end{array}$ & $\begin{array}{l}\text { Design: cross- } \\
\text { sectional } \\
\text { Sample: } \\
\text { random sample } \\
\text { of } 91 \text { high } \\
\text { schools in the } \\
\text { state of } \\
\text { California with } \\
\text { 40,137 students } \\
\text { Variables: } \\
\text { cigarette and e- } \\
\text { cigarette offers } \\
\text { to high school } \\
\text { students, and } \\
\text { demographic } \\
\text { characteristics } \\
\text { and smoking } \\
\text { behavior } \\
\text { Instrument: } \\
\text { questionnaire } \\
\text { Analysis: } \\
\text { descriptive } \\
\text { analysis and } \\
\text { logistic } \\
\text { regression } \\
\text { models }\end{array}$ & $\begin{array}{l}\text { The results of the study } \\
\text { stated that } \\
\text { demographic } \\
\text { characteristics indicate } \\
\text { that male sex is more } \\
\text { likely to be offered } \\
\text { than female sex, on } \\
\text { average } 11.1 \% \text { of } \\
\text { California students in } \\
\text { grades } 10 \text { and } 12 \\
\text { reported that they } \\
\text { were offered e- } \\
\text { cigarettes. Students } \\
\text { with friends who } \\
\text { smoked also had a } \\
\text { higher chance of being } \\
\text { offered e-cigarettes in } \\
\text { the past } 30 \text { days, } \\
\text { compared to those } \\
\text { who did not have } \\
\text { friends who smoked. } \\
\text { Student behavior } \\
\text { using e-cigarettes can } \\
\text { be associated with a } \\
\text { high tendency for } \\
\text { sensation seeking. }\end{array}$ & $\begin{array}{l}\text { It can be } \\
\text { concluded that } \\
\text { extrinsic factors, } \\
\text { namely the } \\
\text { influence of the } \\
\text { surrounding } \\
\text { environment } \\
\text { and intrinsic } \\
\text { factors, namely } \\
\text { hope (high } \\
\text { sensation } \\
\text { seeking) can } \\
\text { affect } \\
\text { adolescents } \\
\text { using e- } \\
\text { cigarettes or } \\
\text { vapor. }\end{array}$ & Pubmed \\
\hline 10 & $\begin{array}{l}\text { A } \\
\text { Randomize } \\
d \text { Trial of } \\
\text { the Effect } \\
\text { of Youth } \\
\text { Appealing } \\
\text { E-Cigarette } \\
\text { Advertisin } \\
g \quad \text { on } \\
\text { Susceptibil } \\
\text { ity to Use } \\
\text { E- } \\
\text { Cigarettes } \\
\text { Among } \\
\text { Youth }\end{array}$ & $\begin{array}{l}\text { Padon, } \\
\text { et al., } \\
2018\end{array}$ & $\begin{array}{l}\text { Design: } \\
\text { descriptive } \\
\text { correlation } \\
\text { Sample: } 417 \\
\text { nonsmoking } \\
\text { youths with a } \\
\text { mean age of } 15 \\
\text { years. } \\
\text { Variable: effect } \\
\text { of e-cigarette } \\
\text { advertising and } \\
\text { belief on e- } \\
\text { cigarette a } \\
\text { Instrument: an } \\
\text { questionnaire } \\
\text { using an an }\end{array}$ & $\begin{array}{l}\text { The results of this } \\
\text { study stated that } \\
\text { adolescents after } \\
\text { seeing e-cigarette } \\
\text { advertisements were } \\
\text { more likely to be } \\
\text { interested in using } \\
\text { them. More than } 25 \% \\
\text { of adolescents think } \\
\text { that using e-cigarettes } \\
\text { will help them look } \\
\text { cool and } 22 \% \text { think } \\
\text { they are fun, and teens } \\
\text { believe that e- } \\
\text { cigarettes are healthy. }\end{array}$ & $\begin{array}{l}\text { It can be } \\
\text { concluded that } \\
\text { extrinsic factors, } \\
\text { namely the } \\
\text { influence of the } \\
\text { surrounding } \\
\text { environment } \\
\text { due to e- } \\
\text { cigarette } \\
\text { advertisements } \\
\text { and intrinsic } \\
\text { factors, namely } \\
\text { hope (helping } \\
\text { them look cool) } \\
\text { can influence } \\
\text { adolescents }\end{array}$ & Pubmed \\
\hline
\end{tabular}




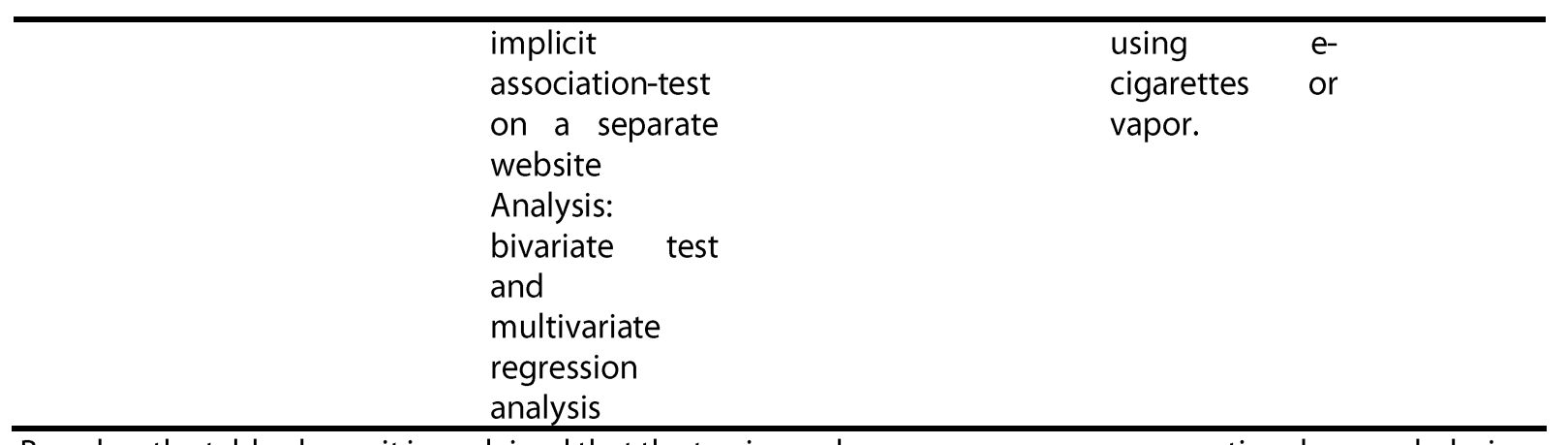

Based on the table above, it is explained that the ten journals on average use a cross-sectional research design, where six of the ten journals use a cross-sectional research design, three of the ten journals use a correlation descriptive design, and one of the ten journals uses a cross-sectional design, experimental and the instrument used in the ten journals is a questionnaire. And the majority use logistic regression analysis, where five of the ten journals use logistic regression analysis, three of the ten journals use chi-square test analysis, two of the ten journals use descriptive analysis and multinomial regression analysis, one of the ten journals uses analysis univariate linear regression, the ten journals used an average sample of adolescents aged 13-17 years with the variables, namely interest, intention, and motivation to use e-cigarettes or vapor, as well as the effect of ecigarette advertising, and smoking status on family and themes.

\section{DISCUSSION Instrinsic Factors}

Intrinsic factors, eight of the ten journals that have been found explain that intrinsic factors affect adolescent motivation to use e-cigarettes or vapor. Intrinsic factors consist of interests, expectations and needs. Based on research (JK, et al., 2016) with the title "Adolescents' Interest in trying flavored e-cigarettes" with a sample size of 1125 adolescents aged 13-17, using research design: descriptive correlation, using instruments: questionnaires, and using regression analysis. Logistics, the study explains that teenagers are more likely to use e-cigarettes or vapor, there is an interest in trying e-cigarettes or vapor offered by a friend because there are flavors, and teenagers believe that e-cigarettes or vapor are less harmful to health than cigarettes tobacco.

In a study (Tsai, et al. 2018) entitled "Reasons for Electronic Cigarette Use Among Middle and High School Students - National Youth Tobacco Survey, United States, 2016" with a sample size of 20,675 grade students from 6-12 years, using a research design. cross-sectional, using the instrument: the NYTS questionnaire, and using the chi-square test analyst also explained that adolescents who used e-cigarettes or vapors had interest because of the availability of flavors such as mint, candy, fruit, and chocolate, and adolescents believed that e-cigarettes or vapor is less harmful than tobacco cigarettes. The study (JC. Surisa, et al. 2015) entitled "Reasons to use ecigarettes and associations with other substances among adolescents in Switzerland" with a sample size of 621 adolescents, using a cross-sectional research design, using the following instruments: questionnaires, and using analysts: multinominal regression and multivariable analysts explained that the reason for using them was interest because of curiosity about e-cigarettes or vapor. The study (Margolis, et al. 2019) entitled "E-cigarette openness, curiosity, harm perceptions and advertising exposure among US middle and high school students" with a cross-sectional research design, using the instrument: NYTS questionnaire, and using the analysis: Logistic regression and multinominal statistical analysts explain that using e-cigarettes or vapor is an interest because of curiosity and curiosity about e-cigarettes or vapor.

In addition, in a study (AG Cole, et al., 2019) entitled "Offers of Cigarettes and ECigarettes Among High School Students: A Population Study from California", with a sample size: a random sample of 91 high schools in the state of California with 40,137 students, using a cross-sectional design, using instruments: questionnaires, and using analyst: descriptive analysis and logistic regression models, explaining that adolescents using e-cigarettes or vapors have hope because of high sensation seeking. The research (Padon, et al., 2018) entitled "A Randomized Trial of the Effect of Youth Appealing E-Cigarette Advertising on Susceptibility to Use ECigarettes Among Youth", with a research design: descriptive correlation, using instruments: a questionnaire with a test implicit association on a separate website, Research (Khoury, et al., 2016) with the title "Reported electronic cigarette use among adolescents in the Niagara region of Ontario" with sample size: 9th grade students aged 14-15 years as many as 3312 respondents, using the research design: cross-sectional , using the instrument: a questionnaire to assess 
cigarettes, e-cigarettes, and other tobacco use as well as independently assessing health and stress, and using analysis: logistic regression, explaining that using e-cigarettes or vapor is hope because it helps them look cool and something which are interesting. In accordance with the theory (Notoadmojo, S, 2010) that motivation is influenced by the intrinsic factor. Intrinsic factor is the desire to act which is caused by driving factors from within (internal) individuals. Individuals who are driven by intrinsic motivation will only be satisfied if the activities carried out have achieved the results involved in that activity (Notoadmojo, $S, 2010)$. From the research above, it is explained that the instricic factors, namely interests and expectations, affect the motivation of adolescents to use vapor, but the eight journals do not explain that the intrinsic factor, namely the need, can affect the motivation of adolescents to use ecigarettes or vapor.

\section{Extrinsic Factors}

Seven of the ten journals also explained that extrinsic factors influence the motivation of adolescents to use e-cigarettes or vapors. Extrinsic factors consist of environment, family encouragement, and rewards. Based on a study (MI Jongenelis et al., 2019) entitled "Factors associated with intentions to use e-cigarettes among Australian young adult non-smokers" with a sample size of 429 Australians aged 18-25 years, using a cross-sectional research design. , using the instrument: a questionnaire with the provision of a web panel, and using analysts: univariate linear regression, explaining that adolescents using ecigarettes or vapor are the influence of the surrounding environment because friends who smoke, family members who smoke, and positive expectations of e-cigarettes so that attracting teens to use e-cigarettes.

The study (Joung, et al. 2016) entitled "Association between Family and Friend Smoking Status and Adolescent Smoking Behavior and ECigarette Use in Korea" with a sample size of 72,060 middle and high students, used a research design: descriptive correlation, using the following instruments: The 2014 questionnaire consisted of 125 items in 15 health behavior domains, and used descriptive analysis, chi-square tests, and logistic regression analysis, explaining that adolescents using e-cigarettes or vapors are the influence of their surroundings because family members, friends use e-cigarettes or vapor, as well as watching smoking in school influence them to use it. The study (Tsai, et al. 2018) entitled "reasons for using e-cigarettes among middle and high school students" with a sample size of "students in grades 6-12 as many as 20,675 respondents".
In a study (Khoury, et al. 2016) entitled "Reported electronic cigarette use among adolescents in the Niagara region of Ontario" with a sample size: 9 th grade students aged $14-15$ years as many as 3312 respondents, using a research design: cross-sectional, using instruments: questionnaires to assess cigarettes, e-cigarettes, and other tobacco use, as well as assessing health and stress independently, and using logistic regression analysis, explaining that adolescents use e-cigarettes or vapor because of the influence of the surrounding environment, namely family members and friends who use e-cigarettes or vapor. The study (Farrelly, et al. 2015) entitled "A Randomized Trial of the Effect of E-cigarette TV Advertisements on Intentions to Use E-cigarettes", with a sample size of 3,655 adolescents aged 13-17 years, used a research design:

Research (Margolis, et al. 2019) entitled "E-cigarette openness, curiosity, harm perceptions and advertising exposure among US middle and high school students" with research design: crosssectional, instrument: NYTS questionnaire, and using analysis: regression, logistic and multinominal logistic regression, explaining that adolescents use e-cigarettes or vapor due to the influence of the surrounding environment, namely due to exposure to e-cigarette advertisements. Research (AG Cole, et al. 2019) entitled "Offers of Cigarettes and E-Cigarettes Among High School Students: A Population Study from California", with a sample size of "a random sample of 91 high schools in the state of California with 40,137 students", with Research design: cross-sectional, using instruments: questionnaires, and using descriptive analysis and logistic regression models,

In accordance with the theory (Notoadmojo, S, 2010) that motivation is influenced by extrinsic factors. Extrinsic factor is motivation that arises because of outside influence. This motivation uses triggers to get someone motivated, these triggers can be awards, praise, positions, and so on (Notoadmojo, S, 2010). From the research above, it can be proven that extrinsic factors, namely the environment, affect the motivation of adolescents to use vapor, however, the seven journals do not explain that extrinsic factors, namely family encouragement and rewards, can influence adolescent motivation to use e-cigarettes or vapor.

\section{CONCLUSION}

Factors related to motivation to use vapor in adolescents, namely intrinsic factors and extrinsic factors. Eight of the ten journals explained that intrinsic factors influenced motivation to use vapor in adolescents, wherein 
the intrinsic factors were explained because of interest and expectation. In the interest of the majority of adolescents using e-cigarettes or vapor there is interest due to the availability of various kinds of flavors, in the hope it is also explained that in the journal the majority of teenagers use ecigarettes or vapor there is hope because they want to see a tap and be used as a search for high sensation, but on the needs of the ten journals does not explain that the need can affect using ecigarettes or vapor.

\section{REFERENCES}

Alawiyah, S. (2017). Perceptions of e-cigarettes on e-cigarette users in the vaporizer community of Tangerang city. Faculty of Nursing, Islamic State University: Jakarta.

Arinda Veratamala. (2018). Three Types of Vape. Retrieved April 3, 2018, from http://hellosehat.com/pusatkeseh/berhenti-merokok/berbagai-jenisvape-rokok-elektrik/

Ariyanti, O., Ririanty, M., \& Iken, N. (2019). Student Vapor User Behavior and Its Impact on Health. Jumantik Journal, vol.3 No.2.

BPOM RI. (2015). The Dangers of TechnologyWrapped Electronic Cigarettes. vol.16 No.5. Jakarta: BPOM.

Cole, AG, Cummins, SE, \& Zhu, SH (2019). Offers of cigarettes and E-cigarettes among high school students: A population study from California. International Journal of Environmental Research and

Public Health, 16 (7).https://doi.org/10.3390/ijerph160711 43

Damayanti, A. (2016). Use of Electronic Cigarettes in the Surabaya Personal Vaporizer Community. Periodical Journal of Epidemiology, 250-261.

Davidson, K., Brancato, A., Heetderks, P., Mansour, W., Matheis, E., Nario, M.,... Fox, D. (2019). Outbreak of Electronic-Cigarette Associated Acute Lipoid Pneumonia MMWR. Morbidity and

Mortality Weekly Report, 68 (August), 784786.https://doi.org/10.15585/mmwr.mm 6836e1

Ministry of Health of the Republic of Indonesia. (2014). Smoking Behavior of Indonesian Society.

Farrelly, MC, Duke, JC, Crankshaw, EC, Eggers, ME, Lee, YO, Nonnemaker, JM,... Porter, L. (2015). A Randomized Trial of the Effect of E-cigarette TV Advertisements on Intentions to Use E-cigarettes. American Journal of Preventive Medicine, 49 (5), 686- 693.https://doi.org/10.1016/j.amepre.201 5.05.010

Indra, MF "Yesi H., Utami, S. (2015). Psychological Picture of Tobacco Smokers Switching to Using E-Cigarettes (vaporizer). Student Online Journal, volume 2 No.2 Riau University Nursing Study Program.

Jongenelis, MI, Brennan, E., Slevin, T., Kameron, C., Jardine, E., Rudaizky, D., \& Pettigrew, S. (2019). Factors associated with intentions to use e-cigarettes among Australian young adult non-smokers. Drug and Alcohol Review, 38 (5), 579587.https://doi.org/10.1111/dar.12963

Joung, MJ, Han, MA, Park, J., \& Ryu, SY (2016). Association between family and friend smoking status and adolescent smoking behavior and E-cigarette use in Korea. International Journal of Environmental Research and Public Health, 13 (12).https://doi.org/10.3390/ijerph13121 183

J, B Suharjo B, Cahyono. (2008). Modern Lifestyle and Disease. Jogjakarta: Kanisius, p. 108109.

Katherine A. Margolisa, Elisabeth A. Donaldson, David B. Portnoy, Joelle Robinson, Linda J. Neff, and

Ahmed Jamal. (2019). E-cigarette openness, curiosity, harm perceptions and advertising exposure among US middle and high school students. 112: 119-125.

Ministry of Health of the Republic of Indonesia. (2014). The Dangers of Electronic Cigarettes. $\mathrm{MOH}, 1-2$. Retrieved fromhttps://www.depkes.go.id/article/pri $\mathrm{nt} / 20143210002 /$ bahayaelectroniccigarettes.html

Lestari, KS, Humairo, MV, \& Agustina, U. (2018). Formaldehyde Vapor Concentration in Electronic Cigarettes and Health Complaints of Electronic Cigarettes Smokers in Indonesia. Journal of Environmental and Public Health, 2018.https://doi.org/10.1155/2018/9013 430

Nayir, E., Karacabey, B., Krica, O., \& Ozdogan, M. (2016). Electronic Cigarette (E-Cigarette). Journal of Oncological Science, volume 2 issue 1. ELSELVIER.

Notoadmojo, S. (2010). Behavioral Health Sciences. Jakarata: Rineka Cipta.

Nursalam and Efendi, F. (2011). Pendidikanlam Nursing. Jakarta: Salemba Medika.

Padon, AA, Lochbuehler, K., Maloney, EK, \& Cappella, JN (2018). A randomized trial of the effect of youth appealing e-cigarette advertising on susceptibility to use e- 
cigarettes among youths. Nicotine and Tobacco Research, 20 (8), 954961.https://doi.org/10.1093/ntr/ntx155

Pepper, JK, Ribisl, KM, \& Brewer, NT (2016). Adolescents' interest in trying flavored ecigarettes. Tobacco Control, 25, ii62 ii66.https://doi.org/10.1136/tobaccocont rol-2016-053174

Potter \& Perry. (2013). Nursing Fundamentals. Jakarta: EGC.

Putro, KZ (2017). Understand the characteristics and tasks of adolescent development. APLIKASIA, vol.17, No.1 / page: 25-32.

Racmat, M., Thaha, RM, \& syafar, M. (2013). Junior High School Teen Smoking Behavior. National Public Health Journal, vol.7 No. 11.

Septhen P. Robbins, TA (2008). Organizational Behavior. Jakarta: Edward Tanujaya.

Stanbrook, MB (2016). Electronic cigarettes and youth: A gateway that must be shut. Cmaj, $\quad 188 \quad$ (11), 785.https://doi.org/10.1503/cmaj.160728
Surís, JC, Berchtold, A., \& Akre, C. (2015). Reasons to use e-cigarettes and associations with other substances among adolescents in Switzerland. Drug and Alcohol Dependence, 153, 140144.https://doi.org/10.1016/j.drugalcdep .2015 .05 .034

Syarfa, llyati. (2015). a description of the level of knowledge, smoking and nicotine dependent behavior of UIN Syarif Hidayatullah Jakarta students. FKIK UN Syarif Hidayatullah, Jakarta.

Tsai, J., Walton, K., Coleman, BN, Sharapova, SR, Johnson, SE, Kennedy, SM, \& Caraballo, RS (2018). Reasons for Electronic Cigarette Use Among Middle and High School Students - National Youth Tobacco Survey, United States, 2016. MMWR. Morbidity and Mortality Weekly Report, 67 196200.https://doi.org/10.15585/mmwr. mm6706a5

WHO. (2010). Addiction to nicotine gender, women, and the tabocca epidemic. 